Canadian University Music Review

Revue de musique des universités canadiennes

\title{
Ellen T. Harris. Handel as Orpheus: Voice and Desire in the Chamber Cantatas, Cambridge, MA: Harvard University Press, 2001. xii, 430 pp. ISBN 0-674-00617-8 (hardcover)
}

\section{John Mayo}

Volume 23, numéro 1-2, 2003

URI : https://id.erudit.org/iderudit/1014525ar

DOI : https://doi.org/10.7202/1014525ar

Aller au sommaire du numéro

Éditeur(s)

Canadian University Music Society / Société de musique des universités canadiennes

ISSN

0710-0353 (imprimé)

2291-2436 (numérique)

Découvrir la revue

Citer ce compte rendu

Mayo, J. (2003). Compte rendu de [Ellen T. Harris. Handel as Orpheus: Voice and Desire in the Chamber Cantatas, Cambridge, MA: Harvard University Press, 2001. xii, 430 pp. ISBN 0-674-00617-8 (hardcover)]. Canadian University Music Review / Revue de musique des universités canadiennes, 23(1-2), 214-217. https://doi.org/10.7202/1014525ar

All Rights Reserved (c Canadian University Music Society / Société de musique des universités canadiennes, 2004
Ce document est protégé par la loi sur le droit d'auteur. L’utilisation des services d'Érudit (y compris la reproduction) est assujettie à sa politique d'utilisation que vous pouvez consulter en ligne.

https://apropos.erudit.org/fr/usagers/politique-dutilisation/ 


\section{BOOK REVIEWS/RECENSIONS}

Ellen T. Harris. Handel as Orpheus: Voice and Desire in the Chamber Cantatas. Cambridge, MA: Harvard University Press, 2001. xii, 430 pp. ISBN 0-674-00617-8 (hardcover).

The London Daily Post of 15 April 1738 reported that an "Effigie of Mr. Handel the famous composer of Musick, is going to be put in Vaux-Hall-Gardens, at the Expence of Mr. Jonathan Tyers [the owner of Vauxhall]."1 The statue, which was commissioned from the then unknown Louis-Franhois Roubiliac, shows the composer in casual dress strumming on a lyre and looking, to my eyes, more than a little uncomfortable-try the pose for yourself. For those whose classical learning was shaky, John Lockman made the symbolism clear in the London Magazine of May 1738:

Drawn by the fame of these imbower'd retreats,

Orpheus is come from the Elysian seats;

Lost to th' admiring world three thousand years,

Beneath lov'd Handel's form he re-appears. ${ }^{2}$

An engraving of Roubiliac's statue by Francesco Bartolozzi appears on the dust jacket of Ellen Harris's important new study. The comparison of famous composers with the mythological Orpheus is not unusual, and until fairly recently most of us would have accepted that it was their musical powers that were being compared. That still holds true, but Harris also draws our attention to another element of the Orpheus legend. She quotes the Hellenistic poet Phanocles who "specifically relates that Orpheus was killed because after Eurydice's death he was 'the first in Thrace to desire men and to disapprove the love of women"' (p. 32). It is this leitmotif that runs throughout her detailed study of Handel's Chamber Cantatas, still the least known of this composer's works.

So is this another "outing" of Handel? Well, yes and no. Harris supplies a carefully-balanced and admirably-researched account of the cantatas. These works are multi-faceted and her readings of both compositions and context are sympathetic to this fact. In good postmodern fashion she eschews a single point of view and instead invites the reader to participate in the interpretation. Do you need Handel to be gay? Then, you will find evidence to support this. Is it essential to your enjoyment of his music that Handel be heterosexual? In that case you will be comfortable with what is presented here. Are you opposed to

1Otto Erich Deutsch, Handel: A Documentary Biography (London: Adam and Charles Black, 1955), 455.

2Ibid., 462. 
all this hermeneutic musing and only interested in "the facts"? Well there is plenty for you, too, in Harris's discussion of chronology based on archival documents and on paper types and watermarks and rastra rulings. In the end, the author believes, all these interpretations can coexist. The different readings, at one level representing present day battles for political and professional territory, are at another level simply derived from "a deep-seated desire to identify personally with what one loves." Paraphrasing that indomitable eighteenth-century Handelian, Mrs. Delany, Harris states: "I do not write to spread tattle, but so "that you may not be ignorant of the ways of the world"' (p. 24).

One thing that all biographers of Handel have stressed is his independence. Apart from a short stint as an organist in Halle and his time in the opera orchestra in Hamburg he never had what an eighteenth-century musician would call a regular job, except, that is, for his appointment in Hanover, and he was absent from that most of the time. Until he moved into his own London house in 1723 , he managed to ingratiate himself with various aristocratic patrons who provided him with food and accommodation and paid him for his work without it suggesting the kind of servitude that was Bach's lot. This was true for his stay with the Marquis Ruspoli in Italy and also for the time he spent in the Burlington coterie in London and at Cannons, the Edgware home of the Duke of Chandos. During this period, 1706-23, Handel wrote well over 100 Italian cantatas for these aristocratic circles: Harris presents clear evidence that there was a substantial same-sex culture within this environment. (In using the term same-sex rather than homosexual I am following the author, who does so in order to prevent an all too easy, and simplistic mapping of current codes and manners onto eighteenth-century practices).

These vocal chamber works, however, are not all expressions of same-sex love, and those that are, express it in a covert manner. Given eighteenth-century attitudes, this is to be expected; accordingly, two chapters in this study are headed "Code Names and Assumed Identities" and "Silence and Secrecy." Of course there is the danger that once one accepts that there may be hidden meanings in a work then the field can be, potentially, thrown open to a lot of speculation. But in this Harris is a model of caution. She quotes Stephen Hawking as an epigraph to the first chapter: "In general, quantum mechanics does not predict a single definite result for an observation. Instead it predicts a number of different possible outcomes and tells us how likely each of these is" (p. 25; emphasis mine). This is precisely what we get in this book.

For those of you who know the cantatas, the one chosen to open this study may come as something of a surprise. It is Hendel, non pub mia musa with a text by Cardinal Pamphili in which the composer is compared to Orpheus. Most scholars have followed hints given in Mainwaring, Handel's first biographer, and by Charles Jennens, one of his librettists, and have been rather dismissive of the work. I am quoted in this vein at some length by Harris. ${ }^{3}$ She, however,

3Harris, 26. She is referencing J. S. M. Mayo, "Handel's Italian Cantatas," PhD diss., University of Toronto, 1977, 41. 
uses this cantata as the basis for a virtuoso survey of the homoerotic aspects of the Orpheus legend, and of eighteenth-century views of same-sex desire. She concludes that the "... Orpheus cantata reveals ... Pamphili's homoerotic attraction to Handel, and this desire can be found as well in his text of [the oratorio] Il Trionfo del tempo."4

As I have suggested, Harris discovers layers of meaning in these works. Arresta il passo, for example, can be read as the soul pursued by God, that is, as religious allegory, as plain sexual pursuit, or given a political twist by supposing that what is portrayed is Spain pursuing Rome as an ally in the War of Spanish Succession. For the sophisticated Arcadian Academy in Rome, for whom this work was written, "probably all three of these meanings were immediately audible" (p. 161). This book is also good on questions of vocality-that is, whose voice is being heard in any one work. It is the ambiguity of the answers to this question that makes the continuo cantatas especially apt for the projection (or hiding) of multiple meanings. The conventional division of the cantatas into those with continuo accompaniment and those with accompaniment for larger instrumental forces is a rather lazy convenience taken over wholesale from Handel scholar Friedrich Chrysander. Harris uses a more subtle division that differentiates among the instrumental group according to whether there are a number of singers or only one. She also extends her reach to include in this study $\mathrm{Aci}$, Galatea e Polifemo, which, although designated a serenata, belongs in the same tradition, as does, by extension, the English version of this mythological story, Acis and Galatea. Finally, by what some may think is a sleight of hand, she manages to bring in a fascinating close reading of the opera Silla and the first of the English oratorios, Esther.

In the instrumental cantatas with a single singer-usually a soprano-the question of voice becomes especially complex. The use of the soprano range does not immediately connote a female character; "... both female (soprano) and male (castrato) singers performed roles written for either female or male characters"(p. 49). The solo instrumental cantatas, however, do differentiate between male and female roles. The women-Lucrezia, Diana, Armida, Agrippina and others-speak with their own voice, while the men, in the relatively few male solo cantatas that Handel wrote, are distanced by a narrative structure. Harris is well aware that music is not autobiography and that it is "particularly difficult to assess when a composer might be using the voice of a woman as a form of self-expression" (p. 78). Nevertheless she believes that in the portrayal of abandoned women in these works we hear the breadth and depth of Handel's own expressive voice.

Voice in the continuo cantatas is often ambiguous. These pieces are more distanced than the instrumental works and "can be understood equally in male or female voice directed to a male or female beloved"(p. 116). It is here that the reading of same-sex desire becomes one of a number of possible interpretations. Baroque performance practice with its frequent exchange of roles between male castrato and female performers encouraged such gender play,

4Ibid., 45. 
and it is often made even easier by the elimination of clearly gendered references in the texts.

The idea that a work of art can present a straightforward, overt message, and at the same time lend itself to quite different hidden interpretations by insiders, will be familiar to readers who have studied the composition and reception of music in Soviet Russia. What I have revealed of Harris's work so far suggests that this was the case with many of Handel's compositions. But the hidden message was not always a sexual one. Handel's discretion and secrecy in personal matters, the very features of his character that now make it almost impossible for us to unravel his private life with any certainty, made him in his lifetime something of a diplomat. His famous leave of absence in London from the position of maestro di cappella to the Elector of Hanover-a leave that supposedly put him in an embarrassing situation when his Hanover boss became George I of England-was quite probably an absence that was encouraged by his employer. In London, Handel was close to the court of Queen Anne, and to her personal physician, Dr. Arbuthnot, and could relay useful information to the future king. In these circumstances it is not so remarkable that he was quickly reconciled with the House of Hanover. More remarkable is that a few months after George's arrival in London, Handel's opera Silla was performed at Burlington House. Besides unraveling for us the homoerotic aspects of the Burlington circle, Harris draws our attention to Jane Clark's argument that Lord Burlington, outwardly a supporter of the Hanoverian Succession, was a leader of the Jacobite party. This in turn leads to a reading of the opera which sees it as an unflattering portrait of George I. If this is true, Handel was treading a very fine line here. Or perhaps not. The allusions are quite subtle.

I have concentrated on the multiple layers of meaning that Ellen Harris reveals in these Handel works. I should emphasize that there is much else besides. A fine singer herself, Harris is a persuasive reader of musical scores. Her discussion of the use of composed silence in these cantatas and the analogy she draws between this aspect of musical rhetoric and David Garrick's style of acting is particularly interesting. Her comments on the music are always perceptive and send the reader, as such comments should, to the score. This in turn makes one long to hear a performance. That, I think, is high praise for a work of formidable musicological scholarship. In addition one's understanding of the music will be helped by the inclusion of English translations of many of the cantata texts.

There was a time when excellent editing of a scholarly book could be taken for granted, but these days it is becoming the exception rather than the rule. In this case Harvard University Press has done Professor Harris proud. All Handelians must have this book. All scholars of Baroque music ought to own it; and all students needing a model of how to balance "old" and "new" musicology in exactly the right proportions should consult it frequently. 